\title{
Selected Hydrologic Data for the Field Demonstration of Three Permeable Reactive Barriers Near Fry Canyon, Utah, 1996-2000
}

By Chris D. Wilkowske, Ryan C. Rowland, and David L. Naftz

U.S. GEOLOGICAL SURVEY

Open-File Report 01-361

Prepared in cooperation with the

U.S. ENVIRONMENTAL PROTECTION AGENCY,

OFFICE OF AIR AND RADIATION

Salt Lake City, Utah

2002 


\title{
U.S. DEPARTMENT OF THE INTERIOR GALE A. NORTON, Secretary
}

\author{
U.S. GEOLOGICAL SURVEY
}

Charles G. Groat, Director

Any use of trade, product, or firm names in this publication is for descriptive purposes only and does not imply endorsement by the U.S. Government.

For additional information write to:

District Chief

U.S. Geological Survey 2329 West Orton Circle

Salt Lake City, Utah 84119
Copies of this report can be purchased from:

U.S. Geological Survey

Information Services

Building 810

Box 25286, Federal Center

Denver, CO 80225-0286 


\section{CONTENTS}

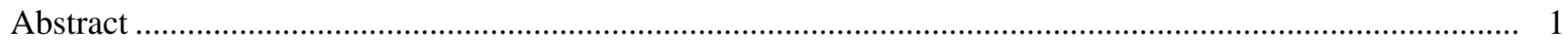

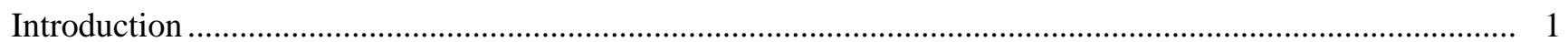

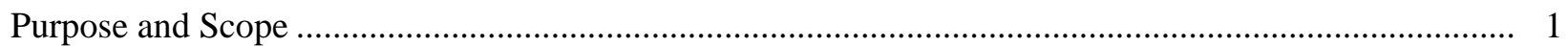

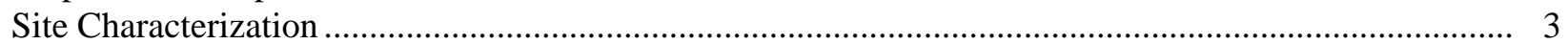

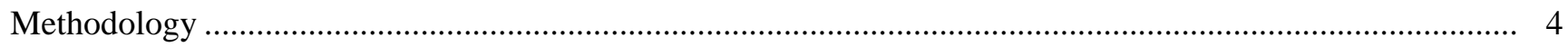

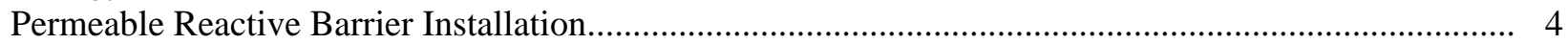

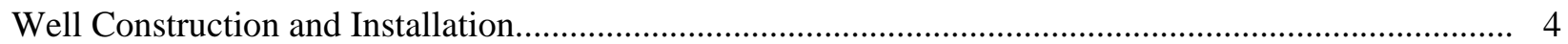

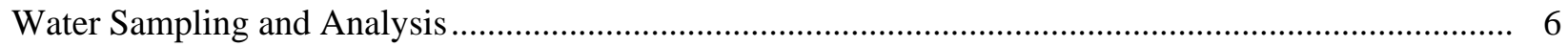

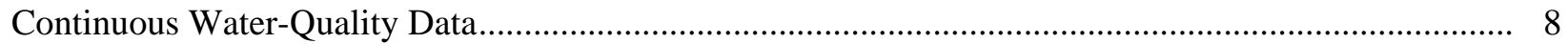

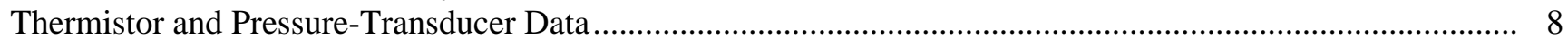

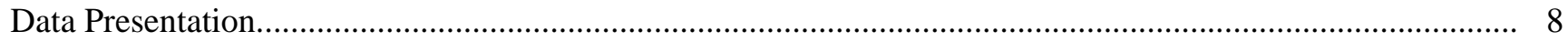

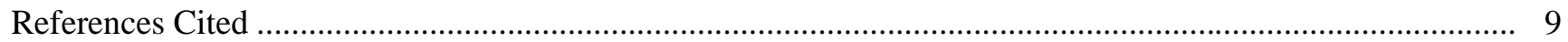


Contents iv 


\section{FIGURES}

Figure 1. Map showing location of the Fry Canyon demonstration site in southeastern Utah..................... 2

Figure 2. Schematic diagram of permeable reactive barriers demonstrated at Fry Canyon, Utah.................. 3

Figure 3. Map showing location of monitoring wells, permeable reactive barriers, and surface-water

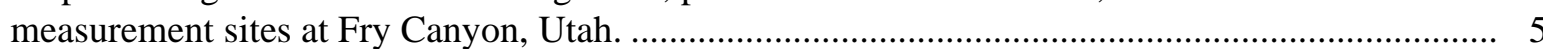

Figure 4. Schematic diagram showing placement of monitoring wells in the zero-valent iron (ZVI) permeable reactive barrier at Fry Canyon, Utah.

Figure 5. Graphs showing seasonal fluctuation in uranium concentration for water from selected wells in and immediately upgradient from the permeable reactive barriers, Fry Canyon, Utah.

Figure 6. Graphs showing mean daily and monthly measured water-level altitude and mean daily water temperature for selected wells in and immediately upgradient from the amorphous ferric oxyhydroxide permeable reactive barrier, Fry Canyon, Utah.

Figure 7. Graphs showing mean daily and monthly measured water-level altitude and mean daily water temperature for selected wells in and immediately upgradient from the phosphate permeable reactive barrier, Fry Canyon, Utah.

Figure 8. Graphs showing mean daily and monthly increased water-level altitude and mean daily water temperature for selected wells in and immediately upgradient from the zero-valent iron permeable reactive barrier, Fry Canyon, Utah.

Figure 9. Graphs showing daily and monthly measured water-level altitude for wells FC-2 and FC-3 and mean daily water temperature for well FC-2, Fry Canyon, Utah.

Figure 10. Graphs showing mean daily and monthly measured water-level altitude and mean daily water temperature for selected wells immediately downgradient from the permeable reactive barriers, Fry Canyon, Utah.

Figure 11. Graphs showing monthy water-level altitude measured in wells within and immediately downgradient from the permeable reactive barriers, Fry Canyon, Utah.

Figure 12. Graphs showing monthly water-level altitude measured in wells near the permeable reactive barriers, Fry Canyon, Utah.

Figure 13. Graphs showing monthly water-level altitude measured in wells immediately upgradient from the permanent reactive barriers, Fry Canyon, Utah.

Figure 14. Graphs showing monthly water-level altitude measured in wells upgradient from the permeable reactive barriers, Fry Canyon, Utah.

Figure 15. Graphs showing mean daily values for water temperature, $\mathrm{pH}$, and specific conductance for water from wells in the permeable reactive barriers, Fry Canyon, Utah.

Figure 16. Graphs showing mean daily values for dissolved-oxygen concentration and Eh for water from wells in the permeable reactive barriers, Fry Canyon, Utah

Figure 17. Graphs showing mean daily values for water temperature, $\mathrm{pH}$, and specific conductance for water from wells FC-2 and FC-3, Fry Canyon, Utah.

Figure 18. Graphs showing mean daily values for dissolved-oxygen concentration and Eh for water from wells FC-2 and FC-3, Fry Canyon, Utah 


\section{TABLES}

Table 1. Well completion data for all wells at the Fry Canyon demonstration site in Utah from 1996 through 1998

Table 2. Discharge, physical properties, and results of chemical analyses for surface- and ground-water samples from sites near the permeable reactive barriers, Fry Canyon, Utah

Table 3. Physical properties and results of chemical analyses for ground-water samples collected in the amorphous ferric oxyhydroxide permeable reactive barrier, Fry Canyon, Utah

Table 4. Physical properties and results of chemical analyses for ground-water samples collected in the phosphate permeable reactive barrier, Fry Canyon, Utah

Table 5. Physical properties and results of chemical analyses for ground-water samples collected in the zero-valent iron permeable reactive barrier, Fry Canyon, Utah 36

Table 6. Mean daily water-level altitude and mean daily water temperature in four wells within and adjacent to the amorphous ferric oxyhydroxide permeable reactive barrier, Fry Canyon, Utah

Table 7. Mean daily water-level altitude and mean daily water temperature in four wells within and adjacent to the phosphate permeable reactive barrier, Fry Canyon, Utah

Table 8. Mean daily water-level altitude and mean daily water temperature in four wells within and adjacent to the zero-valent iron permeable reactive barrier, Fry Canyon, Utah

Table 9. mean daily water-level altitude and mean daily water temperature in monitoring wells FC-2 and FC-3, Fry Canyon, Utah

Table 10. Water-level altitude in selected wells within and adjacent to the permeable reactive barriers, Fry Canyon, Utah

Table 11. Mean daily values for water temperature, $\mathrm{pH}$, specific conductance, and Eh in water from well AFOT3 in the amorphous ferric oxyhydroxide permeable reactive barrier, Fry Canyon, Utah ....... 83

Table 12. Mean daily values for water temperature, $\mathrm{pH}$, specific conductance, and Eh in water from well PO4T3 in the phosphate permeable reactive barrier, Fry Canyon, Utah 86

Table 13. Mean daily values for water temperature, $\mathrm{pH}$, specific conductance, dissolved oxygen, and $\mathrm{Eh}$ in water from well ZVIT3 in the zero-valent iron permeable reactive barrier, Fry Canyon, Utah ... 89

Table 14. Mean daily values for water temperature, $\mathrm{pH}$, specific conductance, and dissolved oxygen in water from well FC-2, Fry Canyon, Utah

Table 15. Mean daily values for water temperature, $\mathrm{pH}$, and specific conductance in water from well FC-3, Fry Canyon, Utah

Table 16. Results of chemical analyses of process blanks collected during each sampling period, Fry Canyon, Utah

Table 17. Results of chemical analyses of duplicate samples from selected wells collected during each sampling period at Fry Canyon, Utah 
CONVERSION FACTORS, VERTICAL DATUM, AND ABBREVIATED

WATER-QUALITY UNITS

\begin{tabular}{rll}
\hline Multiply & \multicolumn{1}{c}{ by } & To obtain \\
\hline cubic foot per second $\left(\mathrm{ft}^{3} / \mathrm{s}\right)$ & 0.02832 & cubic meter per second \\
foot $(\mathrm{ft})$ & 0.3048 & meter \\
gallon (gal) & 0.26425 & liter \\
inch (in.) & 25.4 & millimeter \\
mile (mi) & 0.0254 & meter \\
ounce (oz) & 28.3495 & kilometer \\
ton & 0.907185 & gram \\
\end{tabular}

Water temperature is reported only in degrees Celsius $\left({ }^{\circ} \mathrm{C}\right)$, which can be converted to degrees Fahrenheit $\left({ }^{\circ} \mathrm{F}\right)$ by the following equation:

$$
{ }^{\circ} \mathrm{F}=1.8\left({ }^{\circ} \mathrm{C}\right)+32 .
$$

Sea level: In this report "sea level" refers to the National Geodetic Vertical Datum of 1929-a geodetic datum derived from a general adjustment of the first-order level nets of the United States and Canada, formerly called Sea Level Datum of 1929.

Chemical concentration is reported only in metric units. Chemical concentration in water is reported in milligrams per liter $(\mathrm{mg} / \mathrm{L})$, or micrograms per liter $(\mu \mathrm{g} / \mathrm{L})$, which expresses the solute weight per unit volume (liter) of water. For concentrations less than 7,000 milligrams per liter, the numerical value is about the same as for concentrations in parts per million (ppm). Specific conductance is reported in microsiemens per centimeter at 25 degrees Celsius $(\mu \mathrm{S} / \mathrm{cm})$. Oxidation-reduction potential is reported in millivolts $(\mathrm{mV})$. 


\title{
Selected Hydrologic Data for the Field Demonstration of Three Permeable Reactive Barriers near Fry Canyon, Utah, 1996-2000
}

\author{
By Chris D. Wilkowske, Ryan C. Rowland, and David L. Naftz
}

\section{ABSTRACT}

Three permeable reactive barriers (PRBs) were installed near Fry Canyon, Utah, in August 1997 to demonstrate the use of PRBs to control the migration of uranium in ground water. Reactive material included (1) bone-char phosphate, (2) zero-valent iron pellets, and (3) amorphous ferric oxyhydroxide coated gravel. An extensive monitoring network was installed in and around each PRB for collection of water samples, analysis of selected water-quality parameters, and monitoring of water levels. Water temperature, specific conductance, $\mathrm{pH}$, Eh (oxidation-reduction potential), and dissolved oxygen were measured continuously within three different barrier materials, and in two monitoring wells. Water temperature and water level below land surface were electronically recorded every hour with pressure transducers. Data were collected from ground-water monitoring wells installed in and around the PRBs during 1996-98 and from surface-water sites in Fry Creek.

\section{INTRODUCTION}

Potable ground-water supplies worldwide are contaminated or threatened by advancing plumes containing radionuclides and metals. Pump-and-treat methods are costly and often ineffective in meeting long-term protection standards (Travis and Doty, 1990; National Research Council, 1994; Naftz and others, 1999). Cost effective alternatives to pump-and-treat methods could have widespread applicability to abandoned and active mine sites throughout the United States and other parts of the world. Therefore, an abandoned mine site near Fry Canyon, Utah, was chosen for the field demonstration of three permeable reactive barriers (fig. 1).

Permeable reactive barriers (PRBs) are a potentially cost-effective alternative to pump-and-treat methods. A PRB is a permanent, semi-permanent, or replaceable material that is installed underground across the flow path of a contaminant plume (Remediation Technologies Development Forum Permeable Reactive Barriers Action Team, 1998). A PRB contains a zone of reactive material that acts as a passive in-situ treatment zone. This in-situ treatment zone degrades or immobilizes contaminants, such as radionuclides and other trace elements, as ground water flows through it (fig. 2). Operational and maintenance costs may be lower because water flow across the PRB is driven by the natural gradient and the treatment system does not require operational maintenance or outside power sources. Reactions within the PRB material either degrade contaminants to non-toxic forms or transfer the contaminants to an immobile phase. Potential problems with PRBs include re-release of contaminants through aging reactive material, removal and disposal of the reactive material after breakthrough, and deleterious effects of barrier material on downgradient water quality.

\section{Purpose and Scope}

This report documents, in tabular and graphical form, physical and chemical data collected as part of the site characterization and field demonstration of three PRBs installed at Fry Canyon, Utah, in 1997. Data were collected from ground-water monitoring wells installed in and around the PRBs during 1996-98 and from surface-water sites in Fry Creek. 


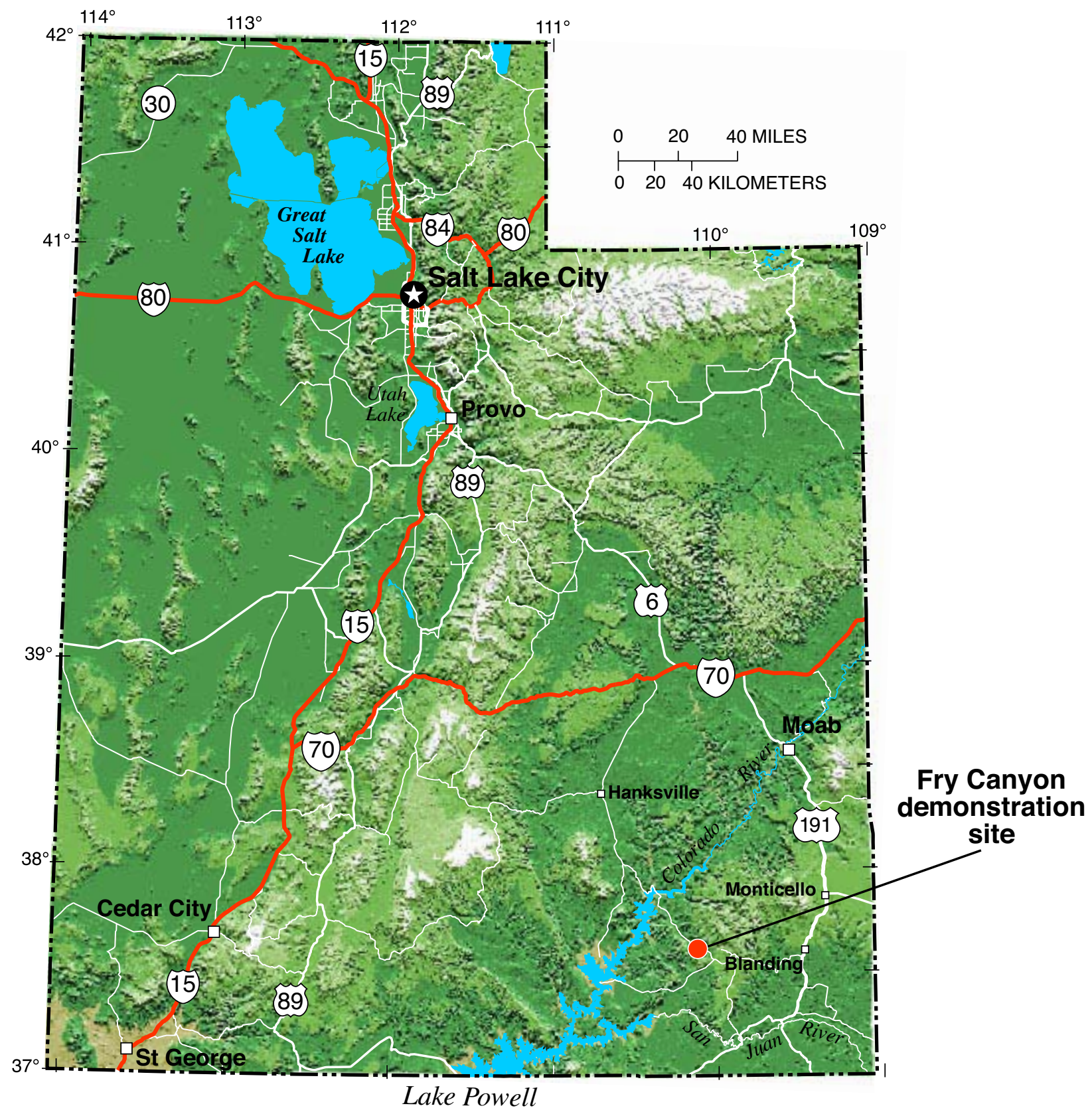

Figure 1. Location of the Fry Canyon demonstration site in southeastern Utah. 


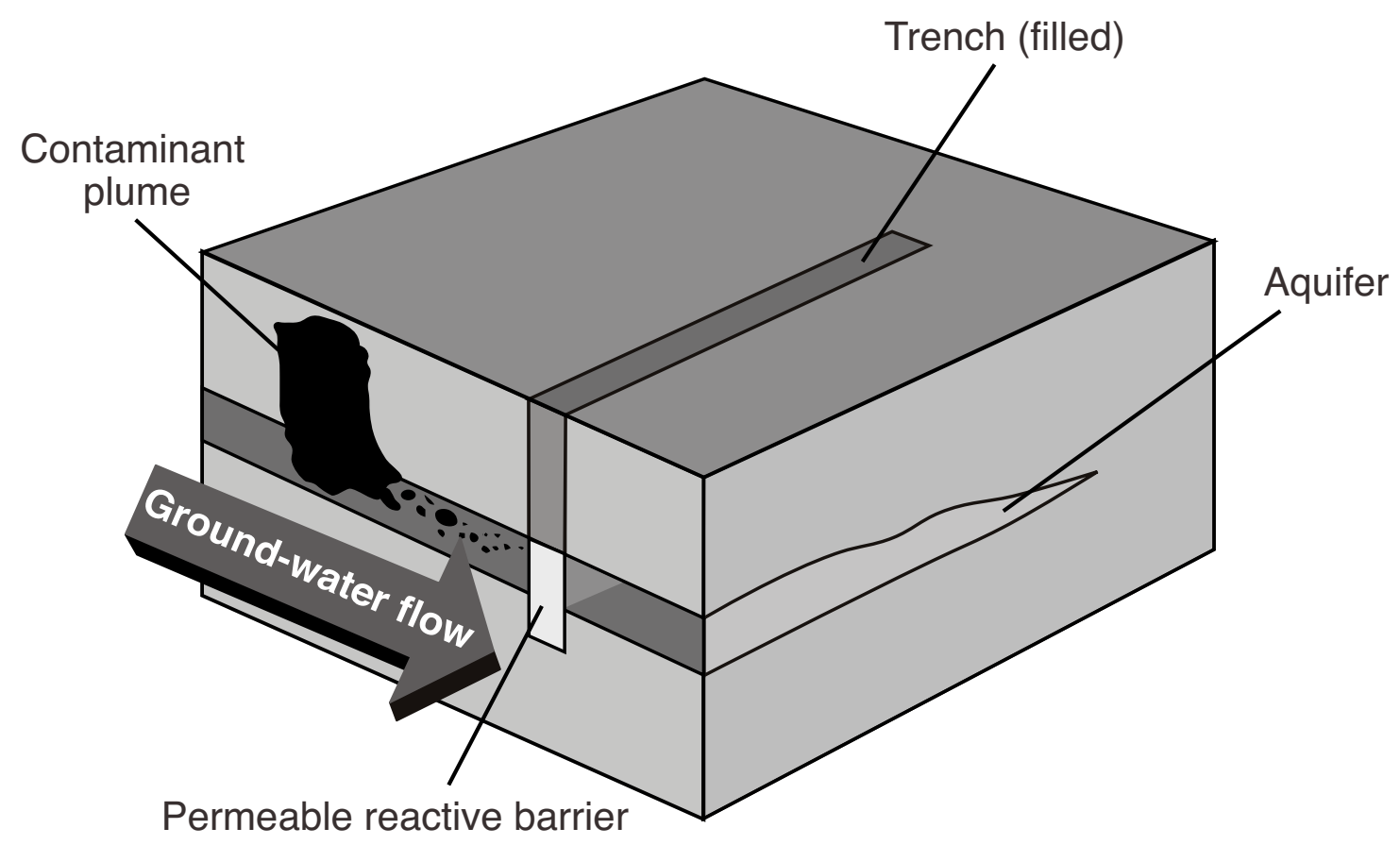

Figure 2. Schematic diagram of permeable reactive barriers demonstrated at Fry Canyon, Utah.

\section{Site Characterization}

Use of PRBs for the remediation of ground water contaminated with chlorinated organic compounds has received considerable attention in recent years $(\mathrm{Gu}$ and others, 1999). In contrast, the application of PRBs to remove uranium and other radionuclides from ground water has been limited. As of 1999, 46 field projects utilized PRBs to treat contaminated ground water; however, only 7 of these field projects are treating $\mathrm{U}$ in water.

One of these seven field projects is located near Fry Canyon, Utah (fig. 1). Three PRBs were installed near Fry Canyon, Utah, in August 1997. The overall objective of this project was to demonstrate the use of PRBs to control the migration of uranium (U) in ground water.
The Fry Canyon site is an abandoned uranium upgrader operation located on Federal land managed by the Bureau of Land Management (BLM). This site is within the arid Colorado Plateau physiographic province at an altitude of approximately 5,400 ft. Air temperature ranges from 30 to $40{ }^{\circ} \mathrm{C}$ in the summer to -10 to $10^{\circ} \mathrm{C}$ in the winter. Average annual precipitation is approximately 9 in. per year. Silt to gravel-size particles derived from nearby sandstone and shale formations make up the shallow, unconfined colluvial aquifer at the site. Maximum thickness of the colluvial deposits is $18 \mathrm{ft}$ and saturated thickness of the aquifer ranges from about 2 to $5 \mathrm{ft}$. Depth to water ranges from 3.03 to $15.79 \mathrm{ft}$ below land surface. Underlying the aquifer is the Permian-age Cedar Mesa Sandstone, which is impermeable compared to the colluvial material. The area is relatively uninhabited except for a ranch and small guest lodge located one half and 2 mi north of the site, respectively. 
The Fry Canyon demonstration site is located adjacent to Fry Creek (fig. 3). Fry Creek is subject to large flash floods resulting from localized thunderstorms that generally occur during July through September. Fry Creek is fed by a series of springs about $820 \mathrm{ft}$ upstream from the ore upgrading facility. Measured discharge ranged from 0 to $0.05 \mathrm{ft}^{3} / \mathrm{s}$; however, stream discharge can exceed $300 \mathrm{ft}^{3} / \mathrm{s}$ during flash floods.

The Fry Canyon site was constructed and operated by COG Minerals Cooperation, a subsidiary of Colorado Oil and Gas Cooperation. The purpose of this facility was to upgrade uranium minerals in ore obtained primarily from three uranium mines in the White Canyon Mining District of southeastern Utah. The upgraded material could then be economically transported about 70 mi to the Texas-Zinc Minerals Cooperation mill at Mexican Hat, Utah.

The upgrader operated during 1957-60 and processed about 50,000 tons of ore containing between 0.10 and 0.15 percent $(\%) \mathrm{U}_{3} \mathrm{O}_{8}$ (Utah Department of Health, 1987). About 40,000 tons of sand tailings, containing about $0.02 \% \mathrm{U}_{3} \mathrm{O}_{8}$, were impounded when the upgrader was closed (Utah Department of Health, 1987).

In 1962, the Fry Canyon site and associated water rights were acquired by the Basin Company for a copper heap leaching operation. This operation used sulfuric acid to leach the copper into solution. The copper was subsequently precipitated with hydrogen sulfide and collected on pieces of scrap iron that are still present at the site. The copper extraction operations ceased in 1968. In 1990 the site was assigned a No Further Action Planned (NFRAP) rating by the U.S. Environmental Protection Agency. The site remained inactive until 1996 when the site was considered for the field demonstration of PRBs for removal of uranium from contaminated ground water (Naftz and others, 2000).

\section{METHODOLOGY}

\section{Permeable Reactive Barrier Installation}

A funnel and gate design was chosen to demonstrate the three PRBs. This design consists of three "permeable windows" or gates in which each of the reactive materials is placed. Each gate is separated by an impermeable wall, and impermeable wing walls are installed on each end of the multi-gate structure to channel the ground water into the PRBs. Impermeable walls were constructed from plywood covered with plastic sheeting and then backfilled with native material. The wing wall on the northeast side of the barriers was constructed with bentonite. Dimensions of each gate structure are $7 \mathrm{ft}$ long by $3 \mathrm{ft}$ wide by about $4 \mathrm{ft}$ deep. The three PRBs and impermeable walls are placed into the upper parts of the bedrock (Cedar Mesa Sandstone) underlying the aquifer. The barrier gravel zone, a 1.5-ft-wide layer of pea gravel, was placed on the upgradient side of the PRBs to facilitate uniform flow of contaminated ground water into each gate structure. The three gates contained (1) bone-char phosphate $\left(\mathrm{PO}_{4}\right)$; (2) zero-valent iron (ZVI) pellets; and (3) amorphous ferric oxyhydroxide (AFO) coated gravel.

The mechanism of $U$ removal in each of the PRBs is a function of the type of barrier gate material used. The $\mathrm{PO}_{4}$ barrier gate material consists of pelletized bone charcoal that facilitates surface complexation of uranium (Fuller and others, 1999). The ZVI material consists of pelletized iron designed to remove uranium by reduction of uranium (VI) to the less soluble uranium (IV). The AFO barrier gate material consists of pea gravel coated with amorphous ferric oxyhydroxide that removes uranium by adsorption. Materials were pelletized or used as a coating on gravel to increase the permeability of the gate structure relative to the permeability of the native aquifer material.

\section{Well Construction and Installation}

Initial background monitoring wells were installed at the Fry Canyon site in September 1996. These wells were drilled using the U.S. Geological Survey (USGS) drilling rig with hollow stem augers. The wells were completed with 2-in.-inner-diameter, flush joint, inside threaded, polyvinyl chloride (PVC) casing with size 10 slotted screen. All wells were completed in the colluvial aquifer and were less than $22 \mathrm{ft}$ in depth. These wells were drilled to the base of the colluvial aquifer and have a $5 \mathrm{ft}$ screened section. The filter pack was constructed with 20-40 sieve silica sand placed in the annular space from the bottom of the borehole to one to three $\mathrm{ft}$ above the top of the well screen. A bentonite seal was placed above the sand 


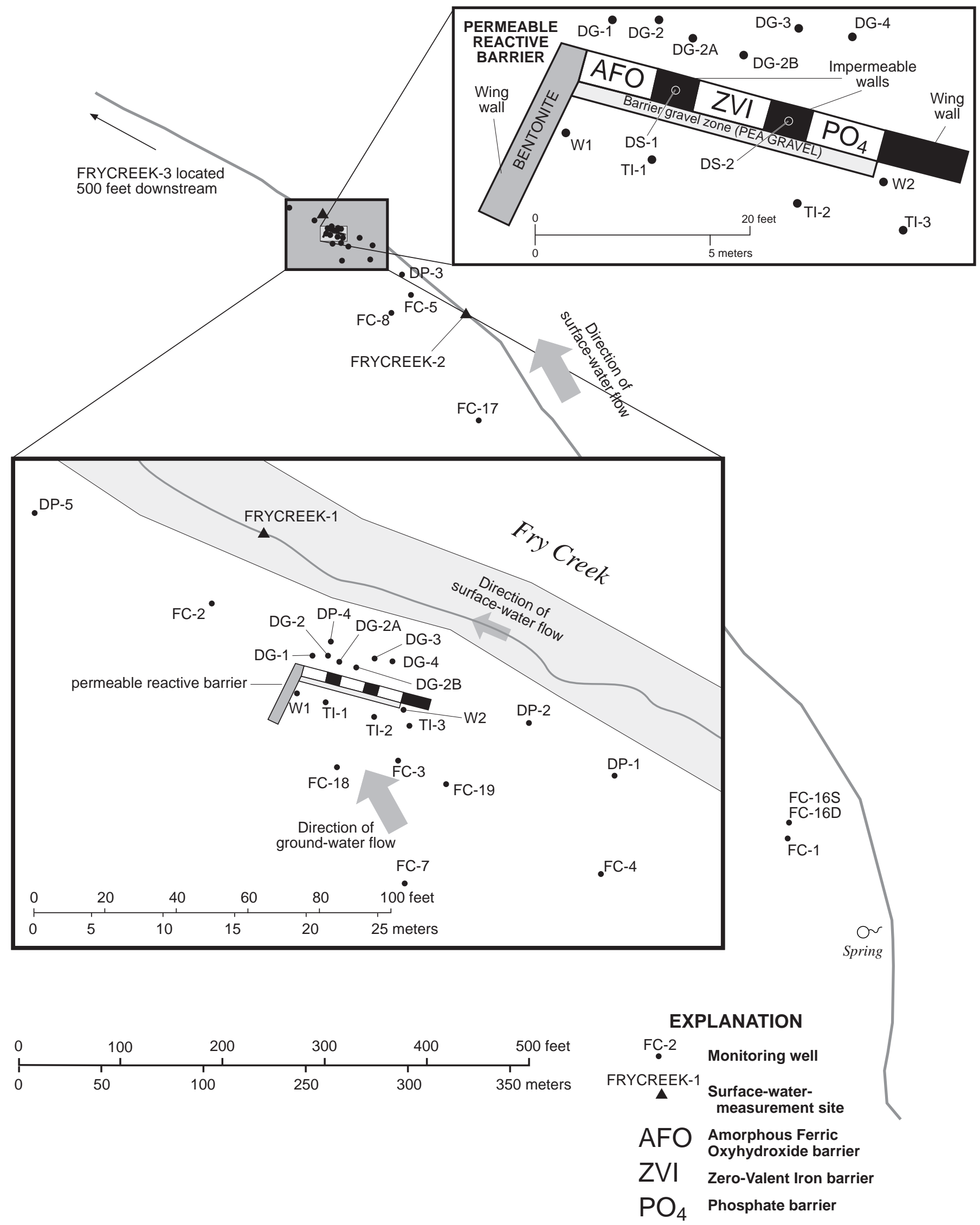

Figure 3. Location of monitoring wells, permeable reactive barriers, and surface-water measurement sites at Fry Canyon, Utah. 
pack and was used to fill the annular space above the seal to about $1 \mathrm{ft}$ below land surface. A cement pad was poured to the surface to anchor a locking steel protective cover. These monitoring wells were designated as FC-1, FC-2, FC-3, FC-4, FC-5, FC-7, and FC-8.

Additional wells were installed at the site in December 1996. These included five steel drive point wells that were installed to the base of the colluvial aquifer. These wells have an inside diameter of 2 in., and a 2.92-ft screened interval. The drive point wells are designated DP-1 through DP-5.

During barrier installation in August and September of 1997, an extensive monitoring network was installed in each PRB. This network consisted of 16 0.25-in.-diameter PVC wells located along two parallel flow paths, and 4 2-in.-diameter PVC wells (fig. 4) for sample collection and monitoring of water levels and selected water-quality parameters. All of the monitoring wells located within the PRBs were installed during construction of the barrier. Casing material was installed to the bottom of the barrier for 3 2-in.-diameter wells and for 10 of the 16 0.25-in.-diameter wells in each barrier. The remaining six 0.25 -in.-diameter wells were installed $1.3 \mathrm{ft}$ from the bottom of the $\mathrm{PO}_{4}$ and ZVI barriers, and $0.66 \mathrm{ft}$ from the bottom of the AFO barrier. The 0.25-in.-diameter wells installed in the barrier have a designation that corresponds to the barrier material (AFO, ZVI, or PO4), which row they are located in (R1 or R2), and a number designating their order in the flowpath. In addition, the first, fourth, and seventh wells in both rows were installed at shallower depths and therefore have the designation " $S$ " before the well number. For example, well ZVIR1S-4 is a 0.25 -in.-diameter well installed in the ZVI barrier, located in row 1 , is a shallow well, and is the fourth well in the row. Two-in.-diameter wells are designated by the barrier they are installed in and by what instruments were installed in the well. Wells with a "T" designation contained pressure transducers; wells with the "FS1" designation were installed for use with a flow sensor. T1 and T2 wells were installed in the barrier gravel zone upgradient of the barrier. T3 and FS1 wells were installed within the barrier material (fig. 4). During this same time period, four 2-in.-diameter monitoring wells were installed downgradient from the barrier with the same method that was described for wells installed in September 1996. These wells are designated DG-1 through DG-4.
In August 1998, 14 additional wells were installed at the Fry Canyon site. These wells were completed in the same manner as the initial wells; however, the holes were drilled with a cable tool rig. Two wells were drilled within the impermeable walls between the barrier materials; these wells are labeled DS-1 and DS-2 (fig. 3). Three wells, TI-1, TI-2, and TI-3, were installed upgradient of the barrier specifically for tracer-injection experiments. Wells $\mathrm{W}-1$ and $\mathrm{W}-2$ were installed to monitor hydrologic effects near the wing walls of the barrier. Wells DG-2a and DG-2b were installed downgradient of the barrier. Well FC-16 is a multiple-level completion well. The borehole was drilled into the bedrock and the deep casing (FC-16D) was placed into the hole. The screened interval was then packed with sand and followed with a bentonite seal. The second casing was then installed (FC-16S), sand packed, sealed with bentonite, and capped with cement and a steel cover. FC-17, FC-18, and FC-19 were all single-level completion wells.

\section{Water Sampling and Analysis}

Because of the proximity of wells to one another, limited purge volumes were extracted prior to sample collection. One gal of water was removed from the 2-in.-diameter monitoring wells and 0.26 gal of water was removed from the 0.25 -in.-diameter monitoring wells. Each 2-in. well contained a dedicated sample tube to minimize cross-contamination during sampling. Pump tubing was connected directly to the 0.25 -in. wells. All purging and sampling was done through a peristaltic pump with low diffusion Norprene tubing. Field parameters, including $\mathrm{pH}$, specific conductance, Eh, water temperature, and dissolved oxygen were continuously monitored during purging with a flow-through chamber attached to either a Yellow Springs Instrument 600XL minimonitor or a Hydrolab Mini-Sonde Water Quality Multi-Probe. Because of the limited purge volumes, ground-water temperature and Eh were not considered to accurately reflect ground-water conditions and therefore are not presented in this report. After purging, water samples for anion analysis were filtered on-site with a 0.45-micron capsule filter and collected in field-rinsed 4-oz polyethylene bottles. Samples for cation analysis also were filtered on-site and collected in 4-oz acid-rinsed bottles. After collection, the cation 


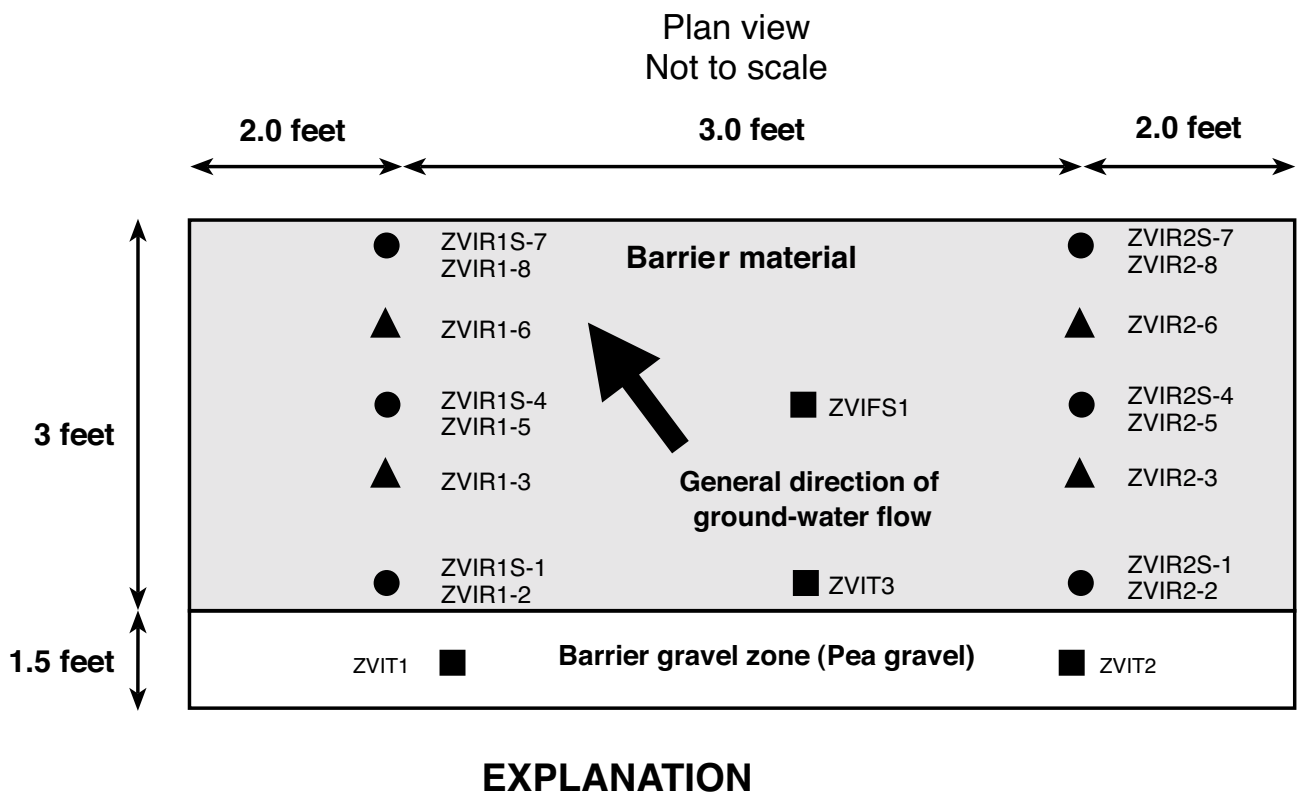

0.25-inch-diameter well, two sampling depths and two wells

0.25-inch-diameter well, one sampling depth

2-inch-diameter monitoring well

The same design is used in the phosphate $\left(\mathrm{PO}_{4}\right)$ and amorphous ferric oxyhydroxide (AFO) barriers.

Figure 4. Schematic diagram showing placement of monitoring wells in the zero-valent iron (ZVI) permeable reactive barrier at Fry Canyon, Utah.

samples were preserved with $1 \mathrm{ml}$ of ultra-pure concentrated nitric acid. Sulfide and phosphate were measured colormetrically in the field with a Chemetrics photometer for selected wells. This was done by first filling a small vial with unfiltered sample water, then immediately breaking a small ampoule containing a reactive solution into the vial. The ampoules are under a negative pressure and, therefore, draw sample water into the ampoule where it is mixed with the reactive solution. After a 1- to 5-minute reaction time, the ampoule is placed in the photometer, which reports the ion concentration of the constituent being measured. Sulfide $\left(\mathrm{S}^{-2}\right)$ was measured in selected wells in the ZVI barrier during April 1998, June 1998, December 1998, December 1999, and June 2000. Phosphate $\left(\mathrm{PO}_{4}{ }^{-3}\right)$ was measured in the $\mathrm{PO}_{4}$ barrier during each sampling event. Detection limits for field-measured phosphate vary because colormetric vials with different ranges of measurement were used during different sampling events. Total alkalinity $\left(\right.$ as $\left.\mathrm{CaCO}_{3}\right)$ of filtered water samples was measured on-site with a $\mathrm{HACH}$ digital titrator and 1.6 normal sulfuric acid.

Water analyses were done at the USGS Research Laboratories in Menlo Park, California. Dissolved U was measured by kinetic phosphorescence analysis. Major cation and trace-element concentrations were measured by inductively coupled plasma optical emission spectrometry by using a Thermo Jarrel Ash ICAP 61 . The potassium concentration was measured by direct air-acetylene flame atomic absorption spectrometry by using a Perkin Elmer AA 603. Sulfate and chloride concentrations were measured by ion chromotography by using a Dionex Chromatograph CHB. Detection limits may vary between sampling events for a particular element as a result of different dilution factors that are used during analysis. Laboratory procedures all followed guidelines established in Standard methods for the examination of 
water and wastewater, $18^{\text {th }}$ Edition (Greenberg and others, 1992). One process blank sample and one field replicate were collected during each sampling period for quality-assurance and quality-control procedures and were analyzed at the USGS Research Laboratories.

\section{Continuous Water-Quality Data}

Water temperature, specific conductance, $\mathrm{pH}$, Eh, and dissolved oxygen were continuously monitored in the barrier gate materials in wells PO4T3, ZVIT3, and AFOT3. These parameters were also measured in wells FC-2 and FC-3. These data were measured every hour with a Yellow Springs Instrument 600XL minimonitor and electronically recorded. The monitors were serviced each month at the Fry Canyon site. Monthly maintenance included cleaning the sensors, replacing all electrolyte solutions, and installing a new semi-permeable membrane on the dissolved-oxygen sensors. After maintenance, the $\mathrm{pH}$, specific conductance, and Eh sensors were recalibrated with known standards. The dissolved-oxygen sensor was calibrated in air by using on-site barometric pressure. Each month, the recorded data were downloaded, processed, and adjusted to remove any drifts in sensor calibration. This was done by applying a correction factor to the data for the downloaded period of record. The correction factor was based on the first stable data point of the next month. For publication purposes in the data tables, a mean daily value for each parameter was calculated and is reported for every fifth day.

Continuous recording of field parameters can be problematic, particularly within the reactive environment of the barriers. After a month of continuous use, the sensors would often become coated by a mineral/biologic film. The coatings were cleaned off once a month prior to calibration; however, it is not known how long it took the coating to reform, or what effect the coating had on sensor readings. The dissolved-oxygen sensor was particularly affected in the AFO and $\mathrm{PO}_{4}$ barriers. Therefore, dissolved-oxygen data from these areas are not presented in this report.

\section{THERMISTOR AND PRESSURE-TRANSDUCER DATA}

Water temperature and water level below land surface were electronically recorded every hour with thermistors and pressure transducers. Once a month, the calibration of the transducers was checked with an electric tape and the data were downloaded. If needed, a correction based on this measure was applied to the period of data collection. Water-level altitudes were then computed from these data. For publication purposes, a mean daily value was calculated and reported for every fifth day.

\section{DATA PRESENTATION}

The location of the Fry Canyon study site in Utah is shown in figure 1. locations of the monitoring wells, PRBs, surface-water sites, and Fry Creek are shown in figure 3 . The detailed emplacement of monitoring wells in each PRB is shown in figure 4. Well-completion data for 90 wells are shown in table 1 . Selected physical properties, trace elements, and major chemical constituents of water collected from surfaceand ground-water sites adjacent to the PRBs are shown in table 2. Selected physical properties, trace elements, and major chemical constituents in ground-water samples collected in the AFO, $\mathrm{PO}_{4}$, and ZVI PRB are shown in tables 3, 4, and 5, respectively. Seasonal fluctuation of uranium concentration in water from wells within and immediately upgradient from the PRBs is shown in figure 5. Depth to water and water temperature were measured continuously with a pressure transducer and thermistor in 12 wells within and adjacent to the $\mathrm{AFO}, \mathrm{PO}_{4}$, and ZVI PRBs. These data were used to calculate mean daily values of water-level altitude and water temperature. Data from every fifth day are listed in tables 6 (AFO), $7\left(\mathrm{PO}_{4}\right)$, and 8 (ZVI), and represented graphically in figures 6 (AFO), $7\left(\mathrm{PO}_{4}\right)$, and 8 (ZVI). mean daily water-level altitude and mean daily water temperature for monitoring wells FC-2 and FC-3 were calculated from pressure transducer and thermistor records and are listed in table 9 and shown graphically in figure 9. mean daily values for water-level altitude and water temperature in wells DG-2, DG-3, and DG-4 are shown in figure 10. Discrete measurements of the depth to water were made each month in the 2-in.-diameter wells. Water-level altitudes were calculated from these 
measurements and are listed in table 10 and shown graphically in figures $11,12,13$, and 14 . Water temperature, $\mathrm{pH}$, specific conductance, and Eh measurements made with a continuous water-quality monitor in water from wells in the $\mathrm{AFO}, \mathrm{PO}_{4}$, and $\mathrm{ZVI}$ PRBs, respectively, are listed in tables 11,12 , and 13. mean daily values for water temperature, $\mathrm{pH}$, specific conductance, and Eh measured with a continuous water-quality monitor for water from monitoring wells in the $\mathrm{AFO}, \mathrm{PO}_{4}$, and ZVI PRB are shown in figure 15. mean daily values for dissolved oxygen and Eh measured with continuous water-quality monitors installed in monitoring wells in the $\mathrm{AFO}, \mathrm{PO}_{4}$, and $\mathrm{ZVI}$ $\mathrm{PRBs}$ are shown in figure 16. mean daily values for water temperature, specific conductance, $\mathrm{pH}, \mathrm{Eh}$, and dissolved oxygen measured with water-quality monitors installed in wells FC-2 and FC-3 are listed in tables 14 and 15, and shown graphically in figures 17 and 18, respectively. Results from the process blank and duplicate samples are listed in tables 16 and table 17 , respectively.

\section{REFERENCES CITED}

Fuller, C.C., Bargar, J.R., Piana, M.J., and Davis, J.A., 1999, Mechanisms of uranium uptake by apatite materials for use in permeable reactive barriers for the remediation of contaminated ground water (abstract), American Geophysical Union Fall Meeting, December 12-17, 1999, San Francisco, Calif., accessed at URL http://agu.org/meetings/waisfm99.html

Greenberg, A.E., Clesceri, L.S., and Eaton, A.D., eds., 1992, Standard methods for the examination of water and wastewater, $18^{\text {th }}$ edition, Washington, D.C., American Public Health Association: American Water Works Association: Water Environment Federation, 1268 p.
Gu, B., Phelps. T.J., Liang, L., Dickey, M.J., Roh, Y., Kinsall, B.L., Palumbo, A.V., and Jacobs, G.K., 1999, Biogeochemical dynamics in zero-valent iron columns: Implications for permeable reactive barriers. Environmental Science and Technology, v. 33, no. 33, p. 2170-2177.

Naftz, D.L., Fuller, C.C., Davis, J.A., Piana, M.J., Morrison, S.J., Freethey, G.W., Rowland, R.C., 1999, Field demonstration of permeable reactive barriers to control uranium contamination in ground water, in Wickramanayake, G.B., Gavaskar, A.R., and Chen, A.S.C., eds., The Second International Conference on Remediation of Chlorinated and Recalcitrant Compounds, Monterey, California, May 22-25, 2000, Chemical oxidation and reactive barriers: remediation of chlorinated and recalcitrant compounds (C2-6), p. 281-289.

Naftz, D.L., Fuller, C.C., Morrison, S.J., Davis, J.A., Freethey, G.W., Rowland, R.C., Piana, M.J., Feltcorn, E.M., Wilhelm, R.G., and Blue, J.E., 2000, Field demonstration of permeable reactive barriers to remove dissolved uranium from groundwater, Fry Canyon, Utah, September 1997 through September 1998, Interim report, U.S. Environmental Protection Agency Report EPA 402-C-00-001.

National Research Council, 1994, Alternatives for ground water cleanup, National Academy Press, Washington, D.C., 315 p.

Remediation Technologies Development Forum Permeable Reactive Barriers Action Team, 1998, Permeable reactive barrier installation profile, accessed September 3, 1998, at URL http://www.rtdf.org/barrdocs.htm

Travis, C.C., and Doty, C.B., 1990, Can contaminated aquifers at Superfund sites be remediated?: Environmental Science and Technology, v. 24, p. 1464-1466.

Utah Department of Health, 1987, Preliminary assessment report, Fry Canyon Tailings, Report Number UTD980718688. 